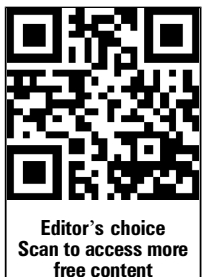

free content

\title{
Results from systematic screening for cardiovascular risk in outpatients with rheumatoid arthritis in accordance with the EULAR recommendations
}

\author{
Jette Primdahl, ${ }^{1}$ Joan Clausen, ${ }^{2}$ Kim Hørslev-Petersen ${ }^{3}$
}

\begin{abstract}
Handling editor Tore K Kvien
${ }^{1}$ Institute for Regional Health Research, University of

Southern Denmark, Hospital of Southern Jutland, Aabenraa and King Christian X's Hospital for Rheumatic Diseases, Graasten, Denmark ${ }^{2}$ Outpatient Department, King Christian X's Hospital for Rheumatic Diseases, Graasten, Denmark

${ }^{3}$ Institute for Regional Health Research, University of Southern Denmark and King Christian X's Hospital for Rheumatic Diseases, Graasten, Denmark
\end{abstract}

\section{Correspondence to} Jette Primdahl, King Christian X's Gigthospital, Toldbodgade 3, Graasten 6300, Denmark: jprimdahl@gigtforeningen.dk

Received 26 March 2013 Revised 24 May 2013

Accepted 26 June 2013 Published Online First 12 July 2013

\section{SLinked}

- http://dx.doi.org/10.1136/ annrheumdis-2013-203688

- http://dx.doi.org/10.1136/ annrheumdis-2013-203911

To cite: Primdahl J, Clausen J, Hørslev-

Petersen K. Ann Rheum Dis 2013;72:1771-1776.

\section{ABSTRACT}

Aim To investigate risk factors for the development of cardiovascular disease (CVD) and estimate the risk of cardiovascular death in rheumatoid arthritis (RA) patients in accordance with EULAR recommendations.

Materials and methods Outpatients with RA $\leq 85$ years of age from a Danish hospital were invited to participate. Patients' risk of cardiovascular death was calculated according to the SCORE system, based on total cholesterol/high-density lipoprotein (HDL) ratio, smoking habits, blood pressure, age and gender. The SCORE was adjusted based on disease duration, IgM-RF/ anti-CCP positivity and the presence of extra-articular manifestations. Factors such as history of CVD, hypertension or diabetes mellitus (DM), fasting glucose, exercise habits, body mass index (BMI) and waist circumference were explored.

Results 836 patients participated; $71.5 \%$ women; mean (SD) age 64.3 years (12.0); $152(19.1 \%)$ were already diagnosed with CVD and 74 (9.0\%) with DM. Among the 644 patients without CVD or DM, 158 (24.5\%) were smokers, $229(35.8 \%)$ had a systolic blood pressure $\geq 140,397$ (65.6\%) total cholesterol $\geq 5.0 \mathrm{mM} / \mathrm{L}, 326$ (55.4\%) low-density lipoprotein cholesterol $\geq 3.0 \mathrm{mM} / \mathrm{L}, 18$ (4.0\%) women and 19 (12.1\%) men had a HDL-cholesterol level below 1.21 $1.0 \mathrm{mM} / \mathrm{L}$. BMI was $>25$ in 409 (63.8\%). Waist circumference was above $80 / 94 \mathrm{~cm}$ in $297(63.3 \%)$ of female and $111(63.8 \%)$ of male patients, respectively, and $418(64.9 \%)$ exercised $\leq 5$ times a week. Among patients without $\mathrm{DM}, 14.3 \%$ had a fasting glucose $\geq 6.0 \mathrm{mmol} / \mathrm{L}$. The SCORE was $\geq 5$ in $122(20.2 \%)$. They were referred to follow-up by their GP and community advice services.

Conclusions Systematic screening revealed several risk factors that needed medical follow-up or support to initiate lifestyle changes.

\section{INTRODUCTION}

It is well documented that people with rheumatoid arthritis (RA) have excess mortality compared to the general population, partly due to an increased risk of cardiovascular events and cardiovascular death. ${ }^{1-3}$ Although people with RA have an increased number of the traditional risk factors for the development of cardiovascular disease (CVD), this does not seem to explain all excess mortality in RA compared to the general population. ${ }^{4}$ It seems likely that the inflammatory process and disease severity also increases the risk of CVD. ${ }^{4-8}$ The excess risk posed by having RA may be compared to the risk from having diabetes mellitus (DM) type II, ${ }^{9-11}$ and is influenced by other disease-related factors and the pharmacological treatment, that is, with glucocorticoids, non-steroidal antiinflammatory drugs, methotrexate, leflunomide and cyclosporine. ${ }^{12}{ }^{13}$ Male gender is associated with a greater risk of CVD. ${ }^{14}$

Longer disease duration, whether the patient is IgM-rheumatoid factor (RF) positive and/or anti-cyclic citrullinated peptide (anti-CCP) positive and the presence of certain extra-articular manifestations seem to be linked with the increased CVD risk due to RA. ${ }^{1}{ }^{15} 16$ In 2010, 10 European League Against Rheumatism (EULAR) recommendations for cardiovascular risk management were published. ${ }^{1}$ Cardiovascular risk assessment in all patients with RA was recommended. Any identified risks should be managed according to local guidelines, and the patient's risk should be scored according to the SCORE system. ${ }^{17}$ The risk SCORE should be adapted by a multiplication factor of 1.5 if the patient met two of the following three criteria: disease duration of more than 10 years, RF and/or anti-CCP positivity and the presence of certain extra-articular manifestations ${ }^{18}$ (pericarditis, pleuritis, Felty's syndrome, polyneuropathy, mononeuritis, scleritis, episcleritis, glomerulonephritis, severe skin vasculitis or vasculitis in other organs). Adequate control of disease activity is also necessary to lower the CVD risk. ${ }^{1}$

To date, only one study has been identified that reported results from the implementation of the EULAR recommendations for cardiovascular risk management in patients with RA. ${ }^{19}$ This Spanish study reported risk scores for 200 patients, but included patients with known CVD and DM, even though the SCORE system is not recommended in these patients. Furthermore, the study included rheumatic nodules in the risk assessment, whereas, in the EULAR recommendations, rheumatic nodules are not on the list of extra-articular manifestations that affect the modified SCORE. ${ }^{1}{ }^{18}$ There is a need for a larger study to assess the impact of risk factors for CVD when implementing the EULAR recommendations.

\section{OBJECTIVE}

The objective was to investigate the spread of traditional risk factors for the development of CVD and the risk SCORE for cardiovascular death when implementing the EULAR recommendations for cardiovascular risk management in a Danish hospital population of outpatients with RA. 


\section{METHODS}

\section{Implementation of the EULAR recommendations}

A multidisciplinary group was established at King Christian X's Hospital for Rheumatic Diseases in Graasten, Denmark, to implement the EULAR recommendations ${ }^{1}$ for RA outpatients at the hospital. The group defined the aim, the content and planned the delivery of the screening consultations. A set of detailed clinical guidelines was developed based on the EULAR recommendations and national guidelines. ${ }^{120-22}$ Screening consultations were to be delivered as 30 -min nursing consultations in addition to the patient's normal follow-up visits. The nurses were offered $4 \mathrm{~h}$ of training covering CVD and risk management, diet and CVD and opportunities in secondary care for lifestyle change support.

\section{Participants}

All outpatients with RA 85 years of age or less connected to King Christian X's Hospital for Rheumatic Diseases in Graasten, Denmark, were invited by a standard letter to a screening consultation.

\section{Study design}

Before the screening consultation, the patients had their fasting glucose, triglycerides, total cholesterol, high density lipoprotein (HDL) cholesterol and low density lipoprotein (LDL) cholesterol levels checked.

The patient's habits regarding smoking (smoker/non-smoker), exercise (less than five times a week/five times a week or more), alcohol (below or above the national recommendations of a maximum seven units per week for women and 14 for men) were explored. The patient's height $(\mathrm{cm})$ and weight $(\mathrm{kg})$ were measured with the patient in light clothes and without shoes, and the patient's body mass index (BMI) was calculated as weight $(\mathrm{kg})$ by squared height $\left(\mathrm{m}^{2}\right)$. Waist circumference $(\mathrm{cm})$ was measured $2 \mathrm{~cm}$ above the patients' umbilicus (midway between the lower rib margin and the iliac crest). ${ }^{14}$ Blood pressure was measured while the patient was sitting in a chair and after at least $5 \mathrm{~min}$ rest. $^{22}$ If the patient's blood pressure exceeded $5 \mathrm{~mm} \mathrm{Hg}$ above the nationally recommended limits, a total of four measures (two on each arm) were performed and the mean of the last two measures was used. ${ }^{22}$ Each patient's risk SCORE was calculated based on age, gender, smoking habits, systolic blood pressure and total cholesterol/HDL ratio. ${ }^{17}$ Denmark was considered to be a high-risk area for CVD in Europe when implementing the screening consultations. In accordance with the EULAR recommendations and national guidelines for the management of RA, ${ }^{1}{ }^{23}$ the risk SCORE was multiplied by 1.5 if the patient fulfilled the above-mentioned criteria. To determine whether the patient had any of the specific extra-articular manifestations, the patient was asked whether a rheumatologist at any time had said that the patient had arthritis apart from in the joints, such as in the eyes, nerves, the vascular system or in other organs. The findings from the screening were discussed with the patient and advice and training in relation to identified risks were offered. Patients were referred to follow-up by the general practitioner (GP) in cases in which the modified risk SCORE was $5 \%$ or greater. Patients with blood pressure above the recommended level, total cholesterol above $8 \mathrm{mmol} / \mathrm{L}$ or fasting glucose of $6 \mathrm{mmol} / \mathrm{L}$ or greater were also referred to their GP. Patients were informed about opportunities to receive additional lifestyle change support in community health centres. Written pamphlets concerning smoking cessation, low-lipid diet and RA were offered.
The patient was offered a page with the actual risk SCORE written on the SCORE chart and the other results from the screening to take home. The findings from the consultations were documented in a Danish rheumatological quality database, the DANBIO registry, and in the patient's journal. Following the consultation, a copy of the note in the journal was sent electronically to the patient's GP. Patients with known DM or CVD or a risk SCORE of $5 \%$ or greater will be invited for a follow-up screening visit in 1 year, if they are interested; patients without known DM or CVD and a SCORE of less than 5\% will be invited for a new screening consultation in 2 years. Patients over the age of 80 years will only be invited again if they express a wish for a new screening consultation.

\section{Statistical analysis}

STATA V.10.1 was used to perform descriptive statistical analyses. Results are reported with mean and SD or median and IQR depending on the distribution of the data. Percentages are calculated based on the number of observations available for each variable.

\section{RESULTS}

From September 2011 to November 2012, 836 patients accepted and completed a screening consultation $(74.3 \%$ of the hospital RA population); 598 (71.5\%) were women. Reasons to decline were due to severe disability or co-morbidities, or that it was difficult for them to attend due to transportation or workrelated issues. Some patients felt that their GP already took care of the content in the screening consultation or that they did not want to discuss lifestyle issues. Approximately $10 \%$ of the patients declined to participate, but the exact number was not recorded.

Patients' disease activity measured by the disease activity score in 28 joints (DAS28)-C reactive protein (CRP) score ${ }^{24}$ and physical disability measured by the health assessment questionnaire (HAQ) ${ }^{25}$ were not recorded in the screening consultations; however, we drew data from an outpatient visit if it was performed within 2 months before or after the screening consultation in order to characterise the population. For some of the patients the most recent follow-up fell outside the 2-month range. DAS28-CRP was thus available in only 526 patients and the HAQ in 626 patients. The demographic and disease-related data relating to the screened population are set out in table 1.

Among the screened patients, 349 (42.0\%) were already diagnosed with hypertension, $152(19.1 \%)$ with ischaemic CVD and $74(9.0 \%)$ with DM.

The spread of the traditional risk factors for ischaemic CVD is reported in table 2 for all 836 patients.

Out of the 748 patients without previously diagnosed DM, $95(14.3 \%)$ had an impaired fasting glucose $(\geq 6.0 \mathrm{mmol} / \mathrm{L})$, which means that DM cannot be excluded. A fasting glucose of 7.0 or greater indicates that the patient probably has undiagnosed DM. A total of 15 patients $(2.0 \%)$ had a fasting glucose of 7.0 or greater.

Out of the 836 screened patients, 644 patients (77\%) were not previously diagnosed with DM or CVD. The number of patients exceeding the recommended levels for each risk factor is shown in table 3.

Thirty-four patients reported that they had both CVD and DM. The recommended level for LDL cholesterol is $1.8 \mathrm{mmol} /$ L or less for this group ${ }^{14}$ and 25 (73.5\%) of these patients did not meet that recommendation. Among the 349 patients with known hypertension who already received antihypertensive 
Table 1 Demographic and disease characteristics of the included population

\begin{tabular}{|c|c|c|}
\hline & & $\mathrm{n}=$ \\
\hline Female gender & & $598(71.5 \%)$ \\
\hline Age, years $($ mean $\pm S D)$ & $64.3(12.0)$ & 836 \\
\hline Disease duration & $9(5-17)$ & 814 \\
\hline Positive anti-CCP & $580(90.5 \%)$ & 641 \\
\hline Positive RF & $690(87.2 \%)$ & 791 \\
\hline CRP $(0-10)$ & $3(1-7)$ & 538 \\
\hline DAS28-CRP (0-10) & $2.4(1.8-3.2)$ & 526 \\
\hline Low (DAS28-CRP <2.6) & $298(56.7 \%)$ & \\
\hline Moderate $(2.6 \leq$ DAS28-CRP $\leq 3.2)$ & $108(20.5 \%)$ & \\
\hline High (DAS28-CRP >3.2) & $120(22.8 \%)$ & \\
\hline HAQ & $0.5(0.125-1.0)$ & 626 \\
\hline Being treated with prednisolone $(0 / 1)$ & $75(9.0 \%)$ & 836 \\
\hline Being treated with DMARD (0/1) & $660(78.9 \%)$ & 836 \\
\hline Being treated with anti-TNF (0/1) & $168(20.1 \%)$ & 836 \\
\hline Known hypertension (0/1) & $349(42.0 \%)$ & 831 \\
\hline Known ischaemic CVD (0/1) & $152(19.1 \%)$ & 794 \\
\hline Men & $53(24 \%)$ & 221 \\
\hline Women & $99(17.3 \%)$ & 573 \\
\hline Known DM (0/1) & $74(9.0 \%)$ & 822 \\
\hline Alcohol above limits (n) & $50(6.4 \%)$ & 787 \\
\hline Women $>7$ units per week & $19(3.4 \%)$ & 560 \\
\hline Men $>14$ units per week & $31(13.7 \%)$ & 227 \\
\hline \multicolumn{3}{|c|}{$\begin{array}{l}\text { Anti-CCP, anti-cyclic citrullinated peptide; anti-TNF, anti-tumour necrosis factor; Being } \\
\text { treated with DMARD, could be one or more disease-modifying antirheumatic drug; } \\
\text { CRP, C-reactive protein; CVD, cardiovascular disease; DAS28-CRP, disease activity } \\
\text { score in } 28 \text { joints, CRP and patient global assessment score; DM, diabetes mellitus, } \\
\text { percentages are calculated based on number of observations for each variable; HAQ, } \\
\text { health assessment questionnaire; ( } n=) \text {, number and percentage of the population; } \\
\text { mean (SD), SD or median (IQR), IQR, as appropriate; RF, rheumatoid factor. }\end{array}$} \\
\hline
\end{tabular}

medication, only 189 (54.2\%) had a systolic blood pressure below $140 \mathrm{~mm} \mathrm{Hg}$.

The SCORE system is not recommended for patients with known CVD and or DM as the SCORE chart will underestimate

Table 2 The spread of cardiovascular risk factors for all the patients with number and percentage of the patients with observations or median and IQR range

\begin{tabular}{lcc}
\hline Variable & All patients & N \\
\hline Current smokers (0/1) (n) & $192(23.0 \%)$ & 836 \\
SBP (mm Hg) & $135(123-144)$ & 830 \\
DBP (mm Hg) & $83(76-90)$ & 829 \\
Total cholesterol (mM/L) & $5.2(4.6-5.9)$ & 794 \\
LDL-cholesterol (mM/L) & $3.0(2.4-3.7)$ & 771 \\
HDL-cholesterol (mM/L) & $1.8(1.5-2.1)$ & 573 \\
$\quad$ Women & $1.5(1.2-1.7)$ & 221 \\
$\quad$ Men & $1.04(0.78-1.39)$ & 791 \\
Triglycerides (mM/L) & $5.4(5-5.7)$ & 729 \\
Fasting glucose (mM/L) & $26.5(23.5-30.3)$ & 833 \\
BMI (kg/m ${ }^{2}$ ) & $85(78-96)$ & 835 \\
Waist circumference (cm) & 597 \\
$\quad$ Women & $99(92-106)$ & 238 \\
$\quad$ Men & $552(66.0 \%)$ & 836 \\
Exercise <5 times a week (n) & & \\
\hline BMI, body mass index calculated as weight (kg)/squared height $\left(\mathrm{m}^{2}\right) ;$ DBP, diastolic \\
blood pressure; HDL, high-density lipoprotein; LDL, low-density lipoprotein; mM/L, \\
milli Mol per litre; SBP, systolic blood pressure. & \\
& &
\end{tabular}

their risk. ${ }^{17}$ Due to a lack of blood test results in some of the 644 patients without known DM and CVD, we only managed to obtain a risk SCORE on 605 patients. In 170 (28.1\%) of these patients the multiplication factor 1.5 was applied.

Based on the European recommendations, a SCORE less than $5 \%$ is considered to be low to moderate risk, $5-10 \%$ is high risk and $10 \%$ or greater is very high risk for cardiovascular death within 10 years. ${ }^{14}$ The risk SCORE are reported in table 4. When Denmark was considered to be a high-risk country, $20.2 \%$ of the patients without previously diagnosed CVD or DM had a high or very high risk $(\geq 5 \%)$ for cardiovascular death within 10 years. Due to a reduced number of cardiovascular deaths, Denmark is now considered to be a low-risk area according to new recommendations from the European and Danish Societies of Cardiology. ${ }^{14} 26$ The number of patients with a SCORE of $5 \%$ or greater thus decreases to $16.2 \%$. The corresponding number for female patients is $11.4 \%$, decreasing to $6.9 \%$ and for male patients $45.3 \%$, decreasing to $42.6 \%$ when using the low-risk score charts. ${ }^{14}$

\section{DISCUSSION}

By implementing systematic screening for cardiovascular risk factors in nursing consultations, the patient, the outpatient department and the patient's GP attained an overview of the patient's individual risk profile. This arrangement also allowed us to explore the patient's motivation for lifestyle changes and offer relevant health promotional training relating to the patient's everyday life, and offer written information (brochures) and support to initiate desired lifestyle changes in primary care.

Initiation or adjustment of lipid-lowering or anti-hypertensive medication or follow-up on lifestyle issues in general would require extra follow-up visits, and we considered that the work involved would lie outside the rheumatologists' core competences. We therefore chose to refer these patients to their GPs. The screened patients seem representative of the more than 16000 Danish RA patients registered in the DANBIO registry (73\% women and $73 \% \mathrm{RF}$ positive). ${ }^{27}$ The patients seen at King Christian X's Hospital for Rheumatic Disease represent more than $90 \%$ of known patients with RA in the uptake area for the hospital. ${ }^{28}$

We found that $14.3 \%$ of the patients without known DM had an impaired fasting glucose $(\geq 6.0 \mathrm{mmol} / \mathrm{L})$, meaning that $\mathrm{DM}$ cannot be excluded. ${ }^{29}$ Two per cent had a fasting glucose of $7 \mathrm{mmol} / \mathrm{L}$ or greater, which is considered in Denmark to be the threshold for diagnosing DM. ${ }^{29}$ The percentages with elevated fasting glucose above 6 and $7 \mathrm{mM} / \mathrm{L}$ were even higher in the subgroup with known CVD (27.2\% and 10.3\%, respectively). In a Danish study from 2003, the prevalence of impaired fasting glucose varied between $4.7 \%$ and $17.8 \%$, depending on age and gender. $^{30}$ The prevalence of DM is increasing and increases with increasing age, BMI, lack of physical activity and male gender. $^{30}$

CVD was already known in $19.1 \%$ of the patients and $42 \%$ were diagnosed with hypertension, compared to $9.3 \%$ with CVD and $32 \%$ with hypertension in a European sample. ${ }^{31}$ Although $42 \%$ of our sample was already treated with antihypertensive drugs, only $54.2 \%$ of these patients had a systolic blood pressure below $140 \mathrm{~mm} \mathrm{Hg}$ at the time of the consultation. The prevalence of a well-treated systolic blood pressure is a little higher in the Danish general population $(63.1 \%) .^{32}$ Unfortunately, $63.8 \%$ in the group who were already known to have CVD had elevated high blood pressure and, among 
Table 3 The number of patients exceeding the recommended levels reported for patients with no known DM or CVD and for the subgroups of patients with known CVD or DM displayed separately

\begin{tabular}{|c|c|c|c|c|}
\hline \multirow{2}{*}{ Variable } & \multicolumn{2}{|c|}{ No DM or CVD } & \multirow{2}{*}{$\begin{array}{l}\text { Known CVD } \\
n=152\end{array}$} & \multirow{2}{*}{$\begin{array}{l}\text { Known DM } \\
n=74\end{array}$} \\
\hline & $\mathrm{n}=$ & & & \\
\hline Women & $448(69.6 \%)$ & 644 & & \\
\hline Current smokers $(0 / 1)$ & $158(24.5 \%)$ & 644 & $26(17.1 \%)$ & $11(14.9 \%)$ \\
\hline Normal BP (SBP <140) & $411(64.2 \%)$ & 640 & $97(63.8 \%)$ & \\
\hline Diabetes patients (SBP <130) & & & $19(26.4 \%)$ & \\
\hline Light HT (SBP 140-159) & $168(26.3 \%)$ & 644 & $38(25.0 \%)$ & \\
\hline Diabetes patients (SBP 130-159) & & & & $44(61.1 \%)$ \\
\hline Moderate HT (SBP 160-179) & $48(7.5 \%)$ & 644 & $12(7.9 \%)$ & $6(8.3 \%)$ \\
\hline Severe HT (SBP $\geq 180)$ & $13(2.0 \%)$ & 644 & $5(3.3 \%)$ & $3(4.2 \%)$ \\
\hline Total cholesterol $\geq 5.0 \mathrm{mMol} / \mathrm{L}$ & $397(65.6 \%)$ & 605 & & \\
\hline Diabetes or CVD ( $\geq 4.5 \mathrm{mM} / \mathrm{L})$ & & & $98(64.5 \%)$ & $41(57.7 \%)$ \\
\hline LDL-cholesterol $\geq 3.0 \mathrm{mMol} / \mathrm{L}$ & $326(55.4 \%)$ & 588 & & \\
\hline Diabetes or $\mathrm{CVD} \geq 1.8 \mathrm{mM} / \mathrm{L})$ & & & $128(84.2 \%)$ & $55(80.9 \%)$ \\
\hline HDL-cholesterol & & 605 & & \\
\hline Women ( $\leq 1.2 \mathrm{mM} / \mathrm{L})$ & $18(4.0 \%)$ & 448 & & \\
\hline Men $(\leq 1.0 \mathrm{mM} / \mathrm{L})$ & $19(12.1 \%)$ & 157 & & \\
\hline Diabetes patients $(\leq 1.0 \mathrm{mM} / \mathrm{L})$ & & & $4(2.6 \%)$ & $2(2.8 \%)$ \\
\hline Triglycerides >1.7 mM/L & $70(11.6 \%)$ & 602 & & \\
\hline Diabetes or CVD $>2.0 \mathrm{mM} / \mathrm{L}$ & & & $17(11.2 \%)$ & $10(14.1 \%)$ \\
\hline F-glucose $\geq 6.0 \mathrm{mmol} / \mathrm{L}$ & $71(12.7 \%)$ & 559 & $37(27.2 \%)$ & \\
\hline F-glucose $\geq 7.0 \mathrm{mmol} / \mathrm{L}$ & $10(1.8 \%)$ & 559 & $14(10.3 \%)$ & $23(36.5 \%)$ \\
\hline Overweight (BMI >25) & $409(63.8 \%)$ & 641 & $96(63.2 \%)$ & $55(74.3 \%)$ \\
\hline Obese (BMI >30) & $163(25.4 \%)$ & 641 & $42(27.6 \%)$ & $29(39.2 \%)$ \\
\hline High waist circumference & & 643 & & \\
\hline Women $(>80 \mathrm{~cm})$ & $297(63.3 \%)$ & 469 & $66(66.7 \%)$ & $42(79.2 \%)$ \\
\hline Men $(>94 \mathrm{~cm})$ & $111(63.8 \%)$ & 174 & $36(67.9 \%)$ & $16(76.2 \%)$ \\
\hline Exercise $<5$ times a week & $418(64.9 \%)$ & 644 & $48(31.6 \%)$ & $54(73.0 \%)$ \\
\hline
\end{tabular}

Table 4 High-risk modified SCORE based on Denmark considered being a high-risk area and the extra RA risk for the 644 patients without DM and CVD, the European low risk area SCORE reports the risk SCORE in the period since Denmark has been considered to be a low-risk area (since May 2012)

\begin{tabular}{|c|c|c|c|}
\hline & $\begin{array}{l}\text { All } \\
n=605\end{array}$ & $\begin{array}{l}\text { Women } \\
n=448\end{array}$ & $\begin{array}{l}\text { Men } \\
\mathrm{n}=157\end{array}$ \\
\hline \multicolumn{4}{|c|}{ European high-risk area RA modified SCORE } \\
\hline Risk SCORE & $2(1,4)$ & $2(1,3)$ & $4(3,7)$ \\
\hline Low/moderate risk & $483(79.8 \%)$ & $397(88.6 \%)$ & $86(54.8 \%)$ \\
\hline High risk & $101(16.7 \%)$ & $48(10.7 \%)$ & $53(33.8 \%)$ \\
\hline Very high risk & $21(3.5 \%)$ & $3(0.7 \%)$ & $18(11.5 \%)$ \\
\hline \multicolumn{4}{|c|}{ European low-risk area SCORE } \\
\hline Low/moderate risk & $529(87.4 \%)$ & $426(95.1 \%)$ & $103(65.6 \%)$ \\
\hline High risk & $67(11.1 \%)$ & $21(4.7 \%)$ & $46(29.3 \%)$ \\
\hline Very high risk & $9(1.5 \%)$ & $1(0.2 \%)$ & $8(5.1 \%)$ \\
\hline \multicolumn{4}{|c|}{ European low-risk area RA modified SCORE } \\
\hline Risk SCORE & $2(1,4)$ & $1.5(1,3)$ & $4(2,6)$ \\
\hline Low/moderate risk & $507(83.8 \%)$ & $417(93.1 \%)$ & $90(57.3 \%)$ \\
\hline High risk & 77 (12.7\%) & 30 (6.7\%) & 47 (29.9\%) \\
\hline Very high risk & $21(3.5 \%)$ & $1(0.2 \%)$ & $20(12.7 \%)$ \\
\hline
\end{tabular}


patients with DM, 73.6\% had blood pressure above the recommended level of $130 \mathrm{~mm} \mathrm{Hg}$.

Inflammation seems to affect the cholesterol level in a paradoxical way, such as a decline in LDL-cholesterol when the patient's CRP level is increased. ${ }^{33}$ The median value and IQR for the CRP and DAS28-CRP (table 1) are within the normal range and thus the lipid paradox may not be applicable for our population. Although quite a few were probably already on lipid-lowering treatment, $55.4 \%$ of the patients without known DM or CVD still had a LDL-cholesterol above $5.0 \mathrm{mmol} / \mathrm{L}$. The situation was even more exacerbated in the group of patients with known CVD (84.2\%) or DM (80.9\%). There seems to be a large gender difference in the percentages with low HDL-cholesterol levels (ratio 3:1 for men/women), whereas this does not seem to the case in the share with high waist circumference; this concurs with the results from a US study. $^{34}$

In 2010, 20.9\% of the general Danish population were smokers and the proportion was $22.2 \%$ for residents in the region of southern Denmark. ${ }^{35}$ Among the screened patients, the number was $23 \%$, decreasing to $17.1 \%$ if the patient had known CVD and $14.9 \%$ in patients with DM, indicating that smoking habits had changed in some patients after diagnosis. In the general population in Denmark $46.7 \%$ are overweight (BMI $>25$ ) and $13 \%$ are obese (BMI >30), and in the region of southern Denmark the numbers are $49.3 \%$ and $14 \% .{ }^{35}$ The share of overweight is about one third higher $(63.8 \%)$ in the screened patients and the number of obese is doubled in persons with RA with or without CVD (27.6/25.4\%) compared to the general population. For people with diabetes, the problem is even greater ( $74.3 \%$ overweight and $39.2 \%$ obese), reflecting the cause for the increasing number of DM type II patients currently. ${ }^{14}$ Unfortunately, there is a positive linear association of BMI and all-cause mortality. ${ }^{14} 36$ The visceral adipose tissue in abdominal fat promotes intracellular inflammatory pathophysiological processes. ${ }^{36}$ Furthermore, the risk of hypertension is up to five times higher in obese individuals than in those with normal weight, and the risk of dyslipidaemia develops progressively with increasing BMI. ${ }^{36}$

A low alcohol intake may have a preventive effect on the development of CVD, whereas heavy drinking seems to increase the risk of CVD. ${ }^{37} 38$ Only $3.4 \%$ of the female and $13.7 \%$ of the male patients reported alcohol intake above the nationally recommended limits of $7 / 14$ units per week, compared to $24.3 \%$ in the Danish general population above the age of 15 years and $20.8 \%$ in the region of southern Denmark. ${ }^{35}$ The main reason for this difference is probably due to the high percentage of patients treated with disease-modifying antirheumatic drugs, in which the number one choice is methotrexate, which requires a need for alcohol restriction. ${ }^{23}$

When the high-risk country charts and RA-modified risk were used, a fifth $(20.2 \%)$ of the patients had an elevated risk of cardiovascular death. Using the SCORE charts for low-risk countries, this number is reduced to $16.2 \%$. The SCORE may underestimate the absolute risk of cardiovascular death in 10 years, because increased disease activity, genetic dispositions to CVD, obesity and lack of exercise will further affect the patient's risk. The risk of cardiovascular events is probably increased even before diagnosis. ${ }^{39}{ }^{40}$ It is very important that the patient's disease activity is treated to target at the same time as we are trying to reduce the patient's risk through the impact from the other risk factors. ${ }^{41}$ In our population, there were still $22.8 \%$ of patients with a DAS28-CRP above 3.2, indicating room for improvement.
In young people the SCORE will be low, regardless of smoking habits, cholesterol and blood pressure levels and thus the chart may underestimate their risk. ${ }^{17}$ In the new European guidelines for prevention of $\mathrm{CVD},{ }^{14}$ it is recommended that young people with a low risk should be scored by a relative risk chart. Furthermore, the SCORE chart only includes age groups up to $65-70$ years, ${ }^{17}$ and thus will probably underestimate the risk for older patients.

One of the strengths of our study is the large number of patients and the systematic documentation in a national registry. Furthermore, most of the hospital population had been invited for a cardiovascular risk assessment during the first 15 months.

The study also had some limitations. Unfortunately, we are not able to report the exact number of patients who declined to participate and compare them to the group who participated to assess potential bias. We did not verify the patients' self-reported version of whether they had extra-articular manifestations of their RA and comorbidities in registry data or in the patients' clinical journals. This may have caused an underestimation of the modified risk scores. Also, we did not include information on whether patients had a family history of CVD, if patients were undergoing lipid-lowering treatment or whether they had severe kidney disease.

The results from this study can help other hospitals plan the resources needed for a systematic approach to screening. As we have reported the SCORE for both high and low-risk countries, other European countries can compare their risk SCORES to the ones reported in this study.

Our results indicate gender differences in lipid status and there are substantial gender differences in the distribution of the risk SCORE. The other risk factors should be further explored for age and gender differences. Future studies need to explore the patients' experiences of screening consultations and reasons to decline participation, and whether the SCORE system provides a realistic estimation of the patients' actual risk of cardiovascular death. This study provides a solid background for a prospective follow-up study to determine whether the patients actually visit their GP as recommended and whether changes in risk and development of CVD occur over time.

\section{CONCLUSIONS}

Systematic screening revealed several risk factors that required medical follow-up or support to initiate lifestyle changes in order to reduce patients' risk of CVD and cardiovascular death. Cardiovascular risk management in patients with already known DM or CVD needs to be improved. When using the charts for high-risk countries, more than 20\% of our patients have an increased risk of cardiovascular death in 10 years. When using the charts for low-risk countries, the number decreases to $16 \%$.

Acknowledgements The authors would like to acknowledge the multidisciplinary group who implemented the systematic screening (senior consultants Lis Smedegaard Andersen and Johnny Raun, head of the secretariat Anette Christensen, head of the department of clinical chemistry Charlotte Drachmann and the outpatient nurses Pia Rhode Rasmussen and Kirsten Nørret Hansen). They would like to thank Niels Steen Krogh from Zitelab and the DANBIO registry for cooperation in development of the CVR theme as part of a yearly visit. They also wish to thank Lorna Campbell for assistance in language editing.

Contributors JP: Study design, data acquisition, data analysis, manuscript drafting. JC: Study design, data acquisition and critical comments to manuscript drafting. KHP: Study design and critical comments to manuscript drafting.

\section{Competing interests None.}

Ethics approval As this was an observational study in which screening consultations were implemented as an integral part of clinical practice at the hospital, ethical approval was not obtained and the patients were not asked for written consent to participate. The patients could decline to participate at any time 
without influencing their follow-up at the hospital in general. We did not invite patients considered have dementia or those over 85 years of age, as we considered it unethical to discuss lifestyle with this group of patients.

Provenance and peer review Not commissioned; externally peer reviewed.

\section{REFERENCES}

1 Peters MJ, Symmons DP, McCarey D, et al. EULAR evidence-based recommendations for cardiovascular risk management in patients with rheumatoid arthritis and other forms of inflammatory arthritis. Ann Rheum Dis 2010;69:325-31.

2 Avina-Zubieta JA, Choi HK, Sadatsafavi M, et al. Risk of cardiovascular mortality in patients with rheumatoid arthritis: a meta-analysis of observational studies. Arthritis Rheum 2008:59:1690-7.

3 Gullick NJ, Scott DL. Co-morbidities in established rheumatoid arthritis. Best Pract Res Clin Rheumatol 2011:25:469-83.

4 del Rincon ID, Williams K, Stern MP, et al. High incidence of cardiovascular events in a rheumatoid arthritis cohort not explained by traditional cardiac risk factors. Arthritis Rheum 2001:44:2737-45.

5 Evans MR, Escalante A, Battafarano DF, et al. Carotid atherosclerosis predicts incident acute coronary syndromes in rheumatoid arthritis. Arthritis Rheum 2011;63:1211-20.

6 Innala L, Moller B, Ljung L, et al. Cardiovascular events in early RA are a result of inflammatory burden and traditional risk factors: a five year prospective study. Arthritis Res Ther 2011:13:R131.

7 Gonzalez A, Maradit Kremers H, Crowson CS, et al. Do cardiovascular risk factors confer the same risk for cardiovascular outcomes in rheumatoid arthritis patients as in non-rheumatoid arthritis patients? Ann Rheum Dis 2008;67:64-9.

8 Solomon DH, Kremer J, Curtis JR, et al. Explaining the cardiovascular risk associated with rheumatoid arthritis: traditional risk factors versus markers of rheumatoid arthritis severity. Ann Rheum Dis 2010;69:1920-5.

9 Lindhardsen J, Ahlehoff $\mathrm{O}$, Gislason $\mathrm{GH}$, et al. The risk of myocardial infarction in rheumatoid arthritis and diabetes mellitus: a Danish nationwide cohort study. Ann Rheum Dis 2011;70:929-34.

10 Peters MJ, van Halm VP, Voskuyl AE, et al. Does rheumatoid arthritis equal diabetes mellitus as an independent risk factor for cardiovascular disease? A prospective study. Arthritis Rheum 2009;61:1571-9.

11 van Halm VP, Peters MJ, Voskuyl AE, et al. Rheumatoid arthritis versus diabetes as a risk factor for cardiovascular disease: a cross-sectional study, the CARRE Investigation. Ann Rheum Dis 2009;68:1395-400.

12 Symmons DP, Gabriel SE. Epidemiology of CVD in rheumatic disease, with a focus on RA and SLE. Nat Rev Rheumatol 2011;7:399-408.

13 Micha R, Imamura F, Wyler von Ballmoos M, et al. Systematic review and meta-analysis of methotrexate use and risk of cardiovascular disease. Am J Cardiol 2011:108:1362-70

14 Perk J, De Backer G, Gohlke H, et al. European Guidelines on cardiovascular disease prevention in clinical practice (version 2012): the Fifth Joint Task Force of the European Society of Cardiology and Other Societies on Cardiovascular Disease Prevention in Clinical Practice (constituted by representatives of nine societies and by invited experts). Atherosclerosis 2012;223:1-68.

15 Turesson C, McClelland RL, Christianson TJ, et al. Severe extra-articular disease manifestations are associated with an increased risk of first ever cardiovascular events in patients with rheumatoid arthritis. Ann Rheum Dis 2007;66:70-5.

16 Turesson C, Jacobsson LT, Sturfelt G, et al. Rheumatoid factor and antibodies to cyclic citrullinated peptides are associated with severe extra-articular manifestations in rheumatoid arthritis. Ann Rheum Dis 2007:66:59-64.

17 Conroy RM, Pyorala K, Fitzgerald AP, et al. Estimation of ten-year risk of fatal cardiovascular disease in Europe: the SCORE project. Eur Heart J 2003:24:987-1003.

18 Turesson C, O'Fallon WM, Crowson CS, et al. Occurrence of extraarticular disease manifestations is associated with excess mortality in a community based cohort of patients with rheumatoid arthritis. J Rheumatol 2002;29:62-7.

19 Gomez-Vaquero C, Robustillo M, Narvaez J, et al. Assessment of cardiovascular risk in rheumatoid arthritis: impact of the new EULAR recommendations on the score cardiovascular risk index. Clin Rheumatol 2012:31:35-9.

20 Hildebrandt P, Larsen ML, Prescott E, et al. Forebyggelse af hjertesygdom (Prevention of heart disease) Dansk Cardiologisk Selskab (Danish Cardiological Association). 2010.http://www.cardio.dk (accessed 15 Aug 2012).

21 Christensen B, Færgemann O, Heebøll-Nielsen, et al. Forebyggelse af iskæmisk hjerte-kar-sygdom i almen praksis (Prevention of ischemic cardiovascular disease in general practice). Dansk Selskab for Almen Medicin (DSAM) (Danish Association for
General Practice) 3rd edn; 2007:52. http://www.dsam.dk/files/9/iskaemisk_hjerte kar_sygdom_2007.pdf (accessed 20 Mar 2013).author initials

22 Bang LE, Christensen KL, Hansen KW, et al. Diagnostisk blodtryksmåling - på døgnbasis, hjemme og i konsultationen. (Diagnostic measurement of bloodpressure —at 24-hour basis, at home and in the consultation). Dansk Hypertensionsselskab (Danisk Hypertension Association) 2006. http://wwwdahs.dk/fileadmin/BTmaaling_ version-17.pdf (accessed 20 Mar 2013).

23 Asmussen KH, Steengaard-Pedersen K, Hørslev-Petersen K, et al. Dansk Reumatologisk Selskabs Kliniske Retningslinje for Klassifikation, Diagnostik, Behandling og Monitorering af Reumatoid Artrtit (RA). (The Clinical Guideline from the Danish Rheumatological Association for Classification, Diagnose, Treatment and Monitoring of Rheumatoid Arthritis (RA). Dansk Reumatologisk Selskab (Danish Rheumatological Association); 2012. http://www.danskreumatologiskselskab.dk/ fileadmin/DRS/kliniskeretningslinjer/Dansk_Reumatologisk_Selskabs_Kliniske_ Retningslinje_for_Diagnostik_Klassifikation_Behandling_og_Monitorering_af Reumatoid_Artrit_revideret_september_2012_PDF_kopi_.pdf (accessed 20 Mar 2013).

24 Prevoo ML, van't Hof MA, Kuper HH, et al. Modified disease activity scores that include twenty- eight-joint counts. Development and validation in a prospective longitudinal study of patients with rheumatoid arthritis. Arthritis Rheum 1995;38:44-8.

25 Thorsen $\mathrm{H}$, Hansen TM, McKenna SP, et al. Adaptation into Danish of the Stanford Health Assessment Questionnaire (HAQ) and the Rheumatoid Arthritis Quality of Life Scale (RAQoL). Scand I Rheumatol 2001;30:103-9.

26 Prescott ER, Rasmussen H, Gustafsson I. 34. Forebyggelse af hiertesygdom (Prevention of heartdisease). Dansk Cardiologisk Selskab (Danish Cardiological Association). 2012. http://nbv.cardio.dk/forebyggelse (accessed 20 Mar 2013).

27 Jensen DV, Hetland M. Danbio, Dansk Reumatologisk Database, Årsrapport 2011. (Danbio, Danish Rheumatological Database, Yearly Report 2011). Danbio, 2012.

28 Pedersen JK. Rheumatoid arthritis in the southern part of Denmark-studies of incidence, prevalence and joint damage related to symptom duration [PhD thesis]. University of Southern Denmark, 2007.

29 Hildebrandt PM, Madsen MM, Egstrup K, et al. Diabetes og Hjertesygdom (Diabetes and heart disease) Dansk Cardiologisk Selskab (Danish Cardiological Association). 2008 http://cardio.synkron.com/sw14033.asp (accessed 20 Mar 2013).

30 Glumer C, Jorgensen T, Borch-Johnsen K. Prevalences of diabetes and impaired glucose regulation in a Danish population: the Inter99 study. Diabetes Care 2003:26:2335-40.

31 Naranjo A, Sokka T, Descalzo MA, et al. Cardiovascular disease in patients with rheumatoid arthritis: results from the QUEST-RA study. Arthritis Res Ther 2008;10: R30.

32 Kronborg C, Hallas J, Jacobsen IA. Prævalens, behandling og kontrol af arteriel hypertension i Danmark—sekundærpublikation (Prevalence, treatment and control of arterial hypertension in Denmark—secondarypublication). Ugeskrift for læger 2009;171:3.

33 Amezaga Urruela M, Suarez-Almazor ME. Lipid paradox in rheumatoid arthritis: changes with rheumatoid arthritis therapies. Curr Rheumatol Rep 2012;14:428-37.

34 Katz PP, Yazdany J, Trupin L, et al. Sex differences in assessment of obesity in rheumatoid arthritis. Arthritis Care Res (Hoboken) 2013;65:62-70.

35 Den nationale sundhedsprofil 2010—Hvordan har du det? (National health profile 2010—How are you?) 1st edn., Islands Brygge 67, 2300 København S: Sundhedsstyrelsen. 2011. http://www.sundhedsprofil2010.dk/Pages/Home.aspx (accessed 20 Mar 2013).

36 Haslam DW, James WP. Obesity. Lancet 2005;366:1197-209.

37 Carlsson AC, Wandell PE, Gigante B, et al. Seven modifiable lifestyle factors predict reduced risk for ischemic cardiovascular disease and all-cause mortality regardless of body mass index: a cohort study. Int I Cardiol Published Online First: 22 Nov 2012 pii: S0167-5273(12)01420-9. doi:10.1016/j.ijcard.2012.10.045

38 Emberson JR, Shaper AG, Wannamethee SG, et al. Alcohol intake in middle age and risk of cardiovascular disease and mortality: accounting for intake variation over time. Am J Epidemiol 2005;161:856-63.

39 Kremers HM, Crowson CS, Therneau TM, et al. High ten-year risk of cardiovascular disease in newly diagnosed rheumatoid arthritis patients: a population-based cohort study. Arthritis Rheum 2008:58:2268-74.

40 Maradit-Kremers H, Crowson CS, Nicola PJ, et al. Increased unrecognized coronary heart disease and sudden deaths in rheumatoid arthritis: a population-based cohort study. Arthritis Rheum 2005;52:402-11.

41 Provan SA, Semb AG, Hisdal J, et al. Remission is the goal for cardiovascular risk management in patients with rheumatoid arthritis: a cross-sectional comparative study. Ann Rheum Dis 2011;70:812-17. 